\title{
IMÁGENES DE DOS REINOS \\ LAS INTERPRETACIONES DEL JUICIO UNIVERSAL EN EL ORBE HISPÁNICO DEL SEISCIENTOS
}

Frente a las aproximaciones tradicionales de la historiografía artística que privilegian el estudio de las fuentes y los modelos iconográficos que se adoptaron en distintas regiones geográficas en un momento dado, han surgido en los últimos años renovadores enfoques que favorecen el estudio del proceso de recepción artística; es decir, el análisis de las circunstancias históricas y los mecanismos culturales a través de los cuales ciertos modelos artísticos fueron privilegiados sobre otros. Siguiendo esta nueva metodología, he emprendido el análisis de ciertas imágenes paradigmáticas dentro del ámbito español del seiscientos; entre ellas destaca la iconografía del Juicio Universal, la cual desempeñó un importante rol como agente de control político-social.

Ciertamente la representación de la Segunda Parusía no ha desmerecido la atención de los manuales iconográficos para la identificación de motivos y fuentes ${ }^{1}$; asimismo, la temática ha sido estudiada en el contexto de la Contrarreforma ${ }^{2}$. Sin embargo, las representaciones del Juicio Universal en España no han sido estudiadas desde el punto de vista de su función y de los tipos de reacciones que ellas despertaron. Elaboradas en los Países Bajos o inspiradas en modelos nórdicos ${ }^{3}$, las representaciones del Juicio Universal proliferaron en la España del siglo XVI conforme a los símbolos de autoridad, justicia y control religioso de la floreciente monarquía unificada. Por aquél entonces, la corona española controlaba regiones diséminadas en el globo: la mayor parte de la península ibérica, y diversas posesiones en Italia, los Países Bajos y América. No obstante, los habitantes de esas regiones poseían idiosincracias muy heterogéneas y percibían la idea de autoridad española de muy diversas maneras.

En este artículo, mi discusión se centrará en las divergentes interpretaciones que las escenas del Juicio final despertaron en dos distintos contextos durante el siglo xvi: la península ibérica y las nacientes colonias españolas en América, tomando en cuenta las circunstancias históricas y culturales dentro de las cuales este tipo de imágenes emergieron. Algunos autores han asociado el auge de escenas escatológicas con tiempos de controversia religiosa ${ }^{4}$, y éste

${ }^{1}$ Cfr. Sebastián, Santiago. Iconografía medieval, San Sebastián, 1988; Esteban Lorente, Francisco. Tratado de Iconografía, Madrid, 1990

${ }^{2}$ Cfr. Martínez-Burgos García, Palma. «El Juicio Final y el problema del desnudo. Interpretaciones», Idolos e imágenes: la controversia del arte religioso en el siglo XVI español, Valladolid, 1989, pp. 253-262.

${ }^{3}$ A pesar de que el tema del Juicio Universal tuvo un importante antecedente entre los siglos XI y xII, los modelos tomados para el revival de los siglos XV y XVI provinieron del Norte. Una influencia general del arte neerlandés en el arte español del gótico tardío puede explicar en parte tal preferencia. Las razones profundas de esta particular preferencia estética son complejas. En general, el arte nórdico desempeñó un rol fundamental en la conformación de una distintiva iconografía religiosa en España. Sin embargo, tales relaciones no han sido hasta el momento estudiadas en profundidad. La mayoría de los estudios sobre arte flamenco en España se han enfocado.hacia las influencias estilísticas sobre artistas locales, dejando de lado otro tipo de contribuciones al vocabulario artístico español. Para estudiar la tradición medieval de Juicios Universales en España ver Esteban Lorente, Op. cit, pp. 256-265; Sebastián, Santiago. Op. cit., pp. 214-219. Para estudiar la influencia del arte flamenco en España en el gótico tardío y el Renacimiento ver Yarza Luaces, Joaquín. Los reyes católicos: paisaje artístico de una monarquía, Madrid, 1993, pp. 378-9; Yarza, Joaquín. «El arte de los Países Bajos en la España de los Reyes Católicos,» Reyes y Mecenas. Los Reyes Católicos, Maximiliano I y los inicios de la Casa de Austria en España, Toledo, 1992, pp. 133-150. Para estudios sobre la influencia estilística del arte flamenco en la pintura española ver Silva Maroto, María Pilar. «Influencia de los grabados nórdicos en la pintura hispanoflamenca», Archivo Español de Arte, vol. 61, julio/sept. 1988, pp. 271-89; Lacarra, M.C. «Influencia de Schongauer en los primitivos aragoneses», BMICA, vol. 17, 1984, pp. 15-39; Angulo Iñiguez, Diego, «Gallego y Schongauer», AEAA, 1930, pp. 74-75. Para una discusión más detallada sobre la influencia nórdica en la temática española del Juicio Universal consultar Domínguez, Mónica. Marten de Vos' Last Judgment for the St. Augustinian Convent at Seville (ensayo inédito).

${ }^{4}$ Para el estudio de las escenas del Juicio Universal en relación con controversias religiosas consultar Harbison, Craig. The Last Judgment in Sixteenth Century Northern Europe: a Study of the Relation Between Art and the Reformation, Nueva York, 1976. Para el mismo argumento en España ver Esteban Lorente, Francisco. Op. cit., p. 256. 
parece ser también el caso de la proliferación de Juicios Universales en el arte español del siglo xvi. Dichas escenas resurgieron en la península ibérica desde mediados del siglo xv, coincidiendo primero con las campañas contra los conversos (es decir, los judíos y musulmanes que, luego de la Reconquista, se convirtieron a la fe católica), y después de 1520, contra los protestantes. Para preservar la unidad política y religiosa en los territorios reconquistados, los Reyes Católicos desplegaron una intensa campaña en favor del Catolicismo, la cual fue institucionalizada en 1487 con el establecimiento de la Inquisición española. En consecuencia, los principales dogmas católicos fueron reforzados, y entre ellos ganó vigor inusitado la idea de Jesús como único mesías y final juez de la humanidad.

De este modo, hacia comienzos del siglo xvi, las escenas de la Segunda Parusía se habrían convertido en lugar común dentro de la cultura española, y sus modelos para la representación artística estarían completamente establecidos. En particular, estas escenas encontraron una interesante manifestación en la naciente tradición de los «retablos de ánimas» ${ }^{5}$. Durante el siglo XV la idea de cofradías de almas, o confraternidades religiosas organizadas alrededor del culto a las almas en el purgatorio, cristalizó definitivamente en los reinos españoles ${ }^{6}$. El purgatorio es, de acuerdo a la teología católica, el lugar o estado después de la muerte donde aquéllos que han muerto en la gracia de Dios, pero no libres de imperfección, expían sus restantes pecados antes de entrar a la visible presencia del Salvador. Este dogma de fe establece que los cristianos vivos pueden ofrecer misas, oraciones, limosnas, y otros actos de piedad y devoción en nombre de aquéllos en el purgatorio ${ }^{7}$. Así, el objetivo de las cofradías de almas era organizar rituales por los miembros fallecidos, para ayudarles a alcanzar la gracia divina. Los miembros de tales asociaciones pertenecían comúnmente a la clase trabajadora, de manera tal que aquéllos que no poseían suficientes recursos para fundar capillas funerarias privadas podían aspirar también a rituales funerarios decentes. Para cumplir con dichas tareas, las cofradías usualmente instalaban un altar o capilla a lo largo de las paredes laterales de las iglesias parroquiales; para esos lugares de oración, fueron encargados los «retablos de ánimas», es decir, retablos con el Juicio Universal como tema central.

Un ejemplo representativo de este tipo de obras lo encontramos en el retablo de las «Mejores y primeras ánimas del purgatorio» (fig. 1) en la iglesia de San Nicolás de Burgos. Encargado por la «Cofradía de las Animas, San Andrés y todos los Santos» ${ }^{8}$ a comienzos del siglo XVI, este panel sigue de cerca el ejemplo magistral realizado por Roger van der Weyden para el hospital de Beaune. Como dominante icono, Cristo-Juez aparece sentado sobre un arcoiris, flaqueado por una lila y una espada, simbolizando respectivamente la inocencia y culpabilidad de aquéllos a quien acaba de separar. Como en el popular modelo flamenco, un San Miguel alado ocupa el segundo punto focal bajo el trono de Dios, desempeñando la psicostasia, o pesaje de almas. Pero a diferencia de la composición flamenca, el arcángel aparece armado, sometiendo con su báculo a Satán. Con su forma de cruz, el báculo además identifica al arcángel como jefe del ejército celestial, rango que lo capacita para administrar justicia. Es significativo que San Miguel vista como guerrero en un país con una larga y aún fresca tradición de órde-

\footnotetext{
${ }^{5}$ Esta categoría es sólo una de las manifestaciones de las escenas del Juicio Universal en España. El tema apareció también en paneles secundarios de retablos mayores; en frescos para salas capiturales y hospitales; como panel central de retablos mayores para iglesias conventuales o en retablos de devoción personal; en sepulcros y capillas funerarias; etc. Sin embargo, la mayoría de esas categorías funcionales no han sido estudiadas. Para el propósito de este estudio, he enfocado mi interés en piezas didácticas elaboradas para ser contempladas por las masas.

${ }^{6}$ Cfr. Ibáñez Pérez, Alberto. Burgos y los burgaleses en el siglo XVI, Burgos, 1990, pp. 369-370

${ }^{7}$ El dogma católico romano del purgatorio fue definido en los concilios de Lyon (1274) y Ferrara-Florencia (1438-45) y reafirmado en Trento (1545-63). Para mayor información sobre el desarrollo del dogma ver Le Goff, Jacques. The Birth of the Purgatory, Chicago, 1984

${ }^{8}$ Cfr. Las edades del hombre: el arte en la Iglesia de Castilla y León, Salamanca, 1988, pp. 338-40
} 


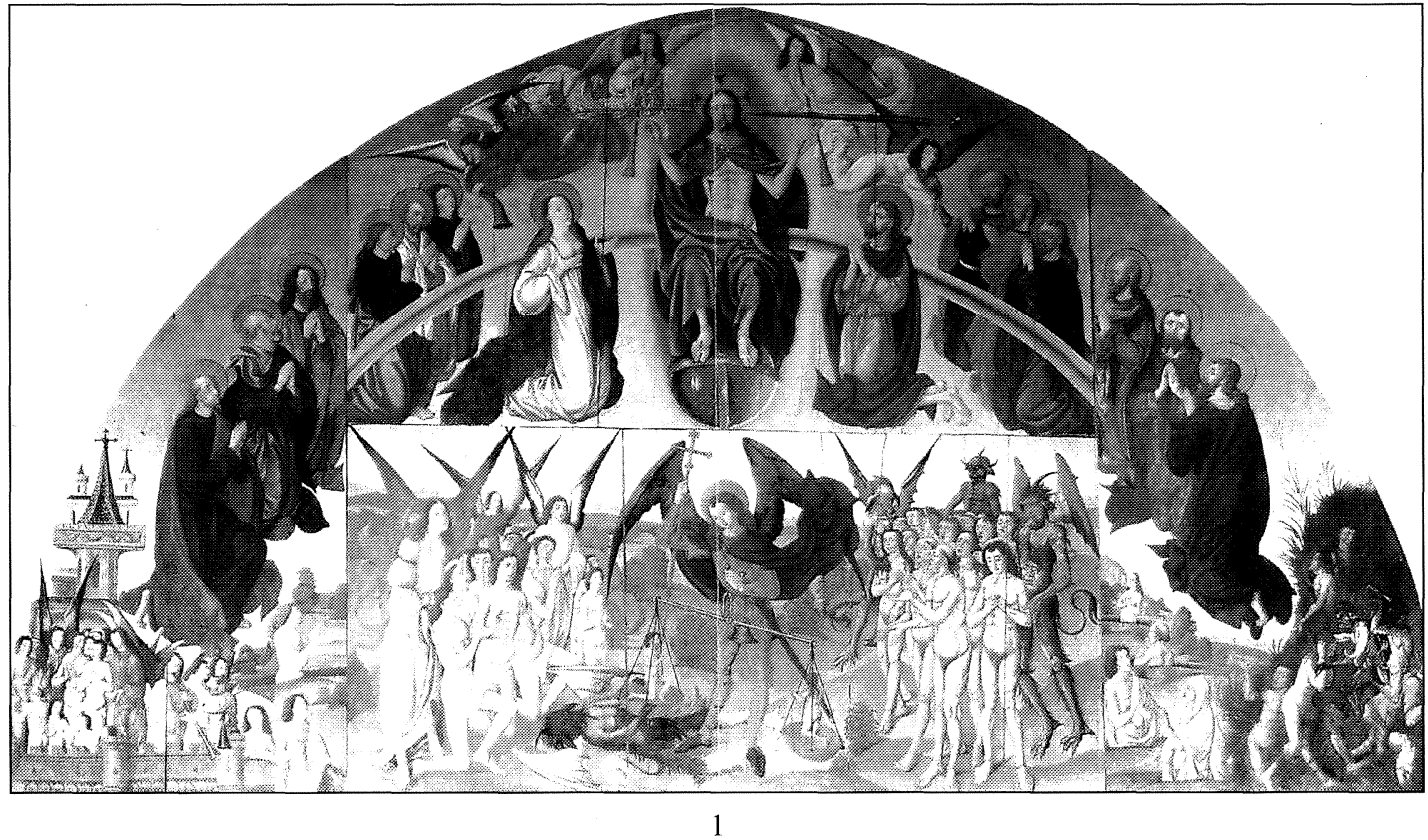

2
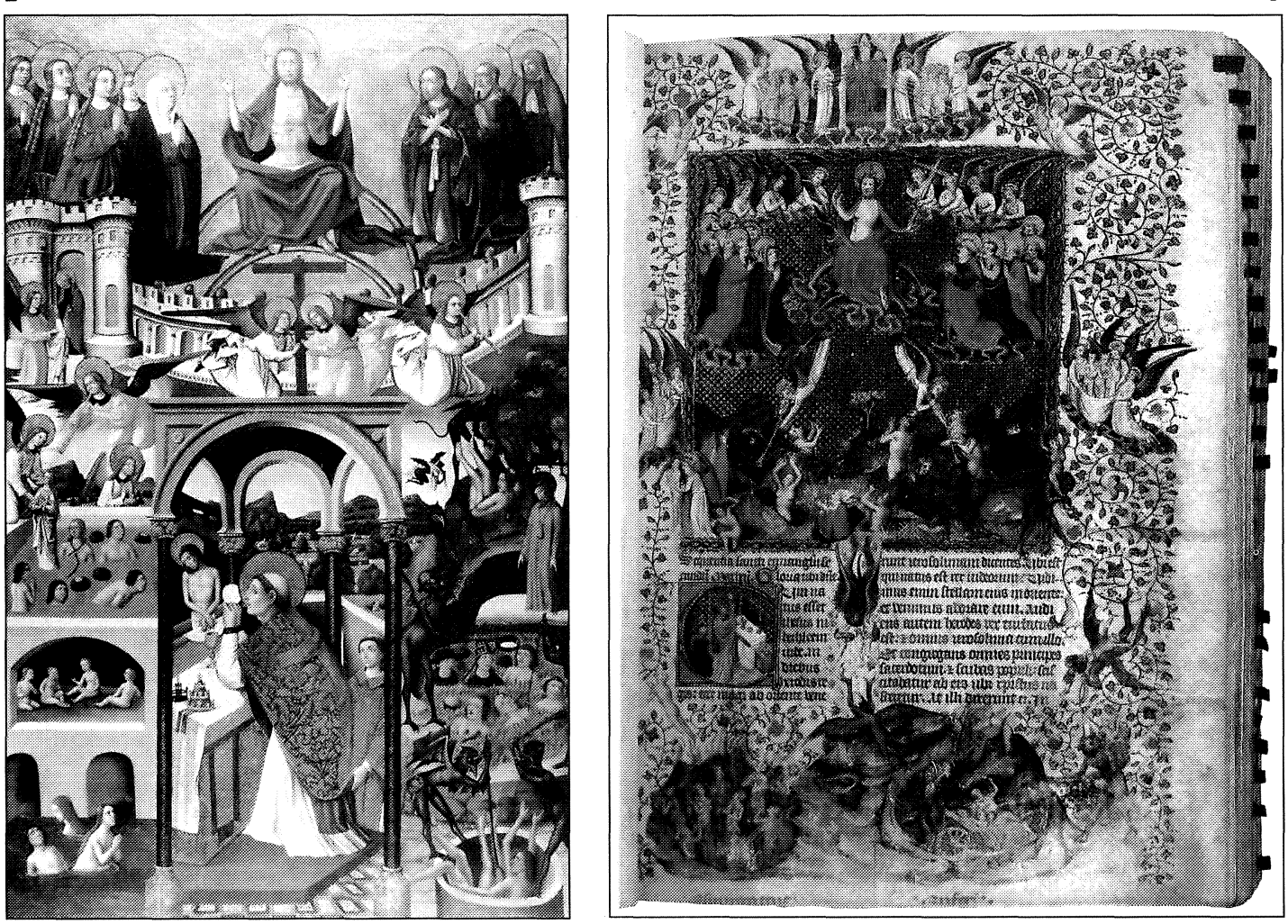

Fig. 1. Anónimo hispano-flamenco, Juicio Final, principios del siglo xvı, Iglesia de San Nicolás, Burgos, España Fig. 2. Maestro de Artés, Retablo de Animas, principios del siglo XvI, Museo de Arte de São Paulo, Brasil. Fig. 3. Anónimo neerlandés (?), Manuscrito iluminado, El Juicio Final con el purgatorio y la Misa de San Gregorio, c. 1412, Walters Art Gallery, Baltimore, EE.UU. 
nes religiosas de caballería. Además, su presencia como representante de Cristo impartiendo justicia debió de tener especial resonancia en un país donde se creía que los inquisidores ejecutaban justicia divina sobre la tierra ${ }^{9}$.

Otra adaptación del modelo nórdico a los esquemas culturales españoles, lo podemos encontrar en la representación del cielo. En la mayoría de las obras flamencas, los electos son conducidos a una iglesia como símbolo del reino del Señor. En éste y en muchos otros ejemplos españoles, las almas de los justos son guiadas a un elegante palacio, sin duda la idea de morada real en la España de aquél entonces. A pesar de que esta recreación tiene su contraparte teológica en los escritos de San Juan Damasceno ${ }^{10}$, es particularmente llamativa la semejanza de este edificio celestial con los alcázares españoles, construidos en diferentes ciudades de la península ibérica entre finales del siglo xv y comienzos del XVI ${ }^{11}$.

Otra codificación de retablos de ánimas se produjo al sur de España, en particular en la provincia de Valencia. Un panel de la mano del Maestro de Artés, actualmente en el Museo de Arte de São Paulo (fig. 2), constituye un clásico ejemplo de este tipo de representaciones, donde la escena del Juicio Final va acompañada por representaciones explícitas del purgatorio ${ }^{12}$. El antecedente más temprano de esta iconografía lo encontramos nuevamente en los Países Bajos, en un manuscrito iluminado en el cual las mismas escenas están representadas en estrecha relación (fig. 3) ${ }^{13}$. Sin embargo, las representaciones españolas mezlan todos esos motivos en una sola composición organizada jerárquicamente, con la escena de la Misa de San Gregorio en el centro. Gregorio el Grande es considerado uno de los «padres del purgatorio» ${ }^{14}$ ya que durante su papado difundió la idea de que misas y oraciones ayudan a redimir a las ánimas en pena. Las escenas del santo al momento de alzar la divina Forma ganaron popularidad en España durante los siglos XIII y XIV ${ }^{15}$. Su inclusión hacia mediados del siglo XV en el contexto del Juicio Universal indudablemente alude al rol central que la Iglesia romana desempeña en el camino hacia el más allá. Mas aun, la presencia de San Pedro a la puerta del cielo enfatiza dicho rol intercesor. En este caso, sin embargo, el paraíso fortificado no luce como un alcázar, pero sí como las ciudades amuralladas de la España de entonces.

Estos retablos de ánimas introducen otros elementos de raigambre popular dentro de la concepción española del otro mundo ${ }^{16}$. Abajo a la izquierda, conseguimos el Limbo donde algunas almas asistidas por las oraciones de sus hermanos disfrutan de un refrigerium entre tormento y tormento ${ }^{17}$; sobre él, en un compartimento estanco, encontramos el Limbo de los

\footnotetext{
${ }^{9}$ La asociación de San Miguel arcángel con la iglesia militante española ha sido ya señalada por algunos autores. Ver Levy, Janey L. The Last Judgment in early Netherlandish painting: faith, authority, and charity in the fifteenth century, Kansas, 1988, pp. 86-7; Berg Sobré, Judith. Behind the Altar Table. The Development of the Painted Retable in Spain, 1350-1500, Columbia, 1989

${ }^{10}$ San Juan Damasceno tuvo una visión del Cielo como una ciudad fortificada con murallas de oro. Cfr. Patch, H.R. El otro mundo en la literatura medieval, México, 1983, pp. 100, 111

"Son particularmente similares los alcázares de Segovia y Toledo.

${ }^{12}$ Otros ejemplos se encuentran en las iglesias parroquiales de Cortes de Arenoso, Quart de Poblet, Onda, Canet Le Roig. Asimismo, en la Colección March de Palma de Mallorca y el Museo de San Carlos en Valencia. Sin embargo, muchos otros ejemplos fueron destruidos durante las revueltas iconoclastas de 1936. Cfr. Sebastián, Santiago. Op. cit. pp. $436-437$.

${ }^{13}$ A pesar de que no existe acuerdo final sobre la proveniencia de este manuscrito, los estudios más recientes señalan un muy probable origen neerlandés. Cfr. Randall, Lilian. Medieval and Renaissance Manuscripts in the Walters Art Gallery, Baltimore-London, pp. 242-3

${ }^{14}$ Cfr. Le Goff, Jacques. Op. cit., pp. 88-95

${ }^{15}$ Sobre la relación existente entre la Misa de San Gregorio y el culto al purgatorio en España ver Trens, Manuel. «La misa y la muerte», La Eucaristía en el Arte Español, Barcelona, 1952, pp. 126-140

${ }^{16}$ Para mayor información sobre las tradiciones medievales españolas alrededor del purgatorio ver Lompart, G. «Aspectos populares del Purgatorio medieval», Dialectología y Tradiciones, vol. 26, t. 4, Madrid, 1970

${ }^{17}$ En España es común encontrar documentos que testimonian que, cuando la conducta en vida del difunto le aseguraba una larga estadía en el purgatorio o en el infierno, las oraciones en su memoria estaban dirigidas a alcanzar recesos o refrigerium durante su tormento. Ver Trens, Manuel, Op. cit., pp. 126,132
}

AEA, LXXV, 2002, 299, pp. 293 a 334 
niños que fallecieron sin la gracia de Dios. Finalmente, el purgatorio es presentado como una piscina repleta de llamas, donde las almas resignadamente esperan a ser rescatadas por un ángel. Ellas experimentan el castigo de fuego, procedimiento muy bien conocido en los dominios españoles gracias a los frecuentes auto de fe ejecutados por la Inquisición ${ }^{18}$.

A la derecha, el infierno se presenta como una caverna con dos enormes ollas, en las cuales demonios grotescos torturan a los condenados. Estas imágenes siguen de cerca la tradicional iconografía infernal del medioevo, en la cual representantes de las diferentes jerarquías sociales reciben su debido tormento de acuerdo al pecado mortal cometido. La noción de castigo infernal había sido diseminada en los reinos españoles por medio de diversos textos apócrifos y doctrinales ${ }^{19}$, muchos de los cuales contenían elocuentes ilustraciones. Asimismo, resulta particularmente llamativo en las representaciones valencianas la figura de Judas colgando en la parte más alta del infierno ${ }^{20}$. Dicha imagen puede ser explicada como una advertencia a todos aquéllos tentados a traicionar la fe católica.

Teóricamente el objetivo de los retablos de ánimas era alterar el tiempo en el más allá, recibiendo las oraciones que ayudarían a las almas en el purgatorio a alcanzar la gloria de Dios. Como tales, ellos representaban paradigmas visuales de lo que se creía serían los tiempos por venir; pero, a través de esos vínculos entre el tiempo terrenal, histórico, y el tiempo escatológico, los cristianos podían asimismo reconocer su propio futuro. Al orar por sus hermanos, tomaban conciencia de su propio destino. Así, estas imágenes cumplían también funciones admonitorias, exhortando a quienes las contemplaban a escoger la vía correcta para alcanzar la gracia divina. Preparando a los fieles para la muerte, dichas imágenes los preparaban también para la vida, ya que la conducta alentada obedecía al mismo tiempo a los ideales políticos y sociales de la corona española.

Siguiendo el mismo espíritu didáctico, las escenas del Juicio Universal cruzaron el Atlántico para asistir en la conversión de los habitantes de la Indias Occidentales. En los virreinatos de la Nueva España (México) y el Perú, las escenas del Juicio Universal fueron usadas por los misioneros para enseñar a los indígenas el concepto foráneo del más allá católico. Uno de los ejemplos más famosos lo encontramos en la capilla abierta del convento agustino de Actopan. Allí, como en muchos otros ejemplos en América, se le concede mayor importancia a los castigos infernales que a la representación de la Segunda Parusía ${ }^{21}$. Este hecho es explicable gracias al carácter evangelizador de estas obras ${ }^{22}$ : al igual que en la península, los religiosos españoles usaron en las colonias americanas la idea de castigo divino no sólo para incitar a los

\footnotetext{
${ }^{18}$ Un estudio semiótico por Maureen Flynn muestra cómo los auto-de-fe españoles imitaban sobre la tierra el concepto de juicio divino; ver Flynn, Maureen, «Mimesis of the Last Judgment: the Spanish auto de fe,» The Sixteenth Century Journal, vol. 22, 1991, pp. 281-97.

${ }^{19}$ Entre los escritos más famosos podemos citar la Visión de Pablo; el Apocalipsis de San Pedro; la Visión del Fray Alberico de Montecassino; el Traitée des peines de l'Enfer por Verard (1480). Ver Sebastián, Santiago. Op. cit., pp. 417.

${ }^{20}$ Cfr. Sebastián, Santiago. Op. cit., pp. 437

${ }^{21}$ Existen otros frescos con las mismas características en la iglesia de Xoxoteco, Hidalgo, y en el claustro agustino de Acolman, Edo. México. Para el estudio iconográfico de imágenes escatológicas en la América hispana consultar Sebastián, Santiago. Iconografía e iconología del arte novohispano, Madrid, pp. 81-82; Estrada de Gerlero, Elena Isabel, «Los temas escatológicos en la pintura mural novohispana del siglo xvı». Traza y Baza, n. ${ }^{\circ}$ 7, 1978, pp. 71-88; Estrada de Gerlero, Elena Isabel, «La escatología en el arte monástico novohispano del siglo xvi». Arte funerario. Coloquio Internacional de Historia del Arte, México, 1987, vol. 1, pp. 137-150. La pintura mural no fue la única técnica para la representación de castigos infernales en las colonias españolas en América. Las ilustraciones del libro Rhetorica Christiana (1579) por el autor novohispano Diego Valadés muestran una amplia gama de castigos infernales; ver Estrada de Gerlero, Elena Isabel, «La demonología en la obra gráfica de Fray Diego Valadés», Iconología y sociedad. Arte colonial hispanoamericano. XLIV Congreso Internacional de Americanistas, México, 1987, pp. 77-89. Asimismo, existieron diversas obras teatrales sobre este tópico; ver Olmos, Andrés de. Auto del juicio final, México, D.F , 1983, para mayor detalle sobre una pieza publicada en México en 1533, tanto en castellano como en nahuatl.

${ }_{22}$ Cfr. Manrique, Jorge Alberto. «La muerte en la Colonia», La Muerte: expresiones mexicanas de un enigma, México, 1975 .
}

AEA, LXXV, 2002, 299, pp. 293 a 334 
indios a la conversión, sino también para forzar su sumisión al nuevo orden político y social.

Es difícil imaginar qué tipo de connotaciones despertaron estas representaciones en las mentes de los naturales. Sin embargo, existen testimonios de que esas imágenes amenazadoras fueron interpretadas en una manera muy particular, al menos en el virreinato peruano. Como Sabine MacCormack ha estudiado detalladamente, después de la invasión europea los andinos adquirieron conocimiento del Juicio Final cristiano, pero en sus propios términos, yuxtaponiéndolo a su noción nativa de pachacuti ${ }^{23}$. Pachacuti es un término dentro de la cosmología andina «que describe la culminación e inversión de un orden establecido, ya sea pasado, presente o futuro» ${ }^{24}$.

Una valiosísima fuente para analizar esta síntesis de conceptos andinos y cristianos ${ }^{25}$ lo encontramos en el libro Coronica i Buen Gobierno escrito por el indígena peruano Felipe Guamán Poma de Ayala ${ }^{26}$. Este manuscrito fue compilado entre 1585 y 1635 como una crónica ilustrada de la historia peruana, que incluye, además, una prescripción para un futuro buen gobierno. En él, el autor da cuenta tanto de las antiguas tradiciones indígenas, como de las costumbres transculturadas del siglo Xvi. Guamán Poma usa el tradicional topoi de los vicios y virtudes cristianas para relatar el estado de cosas en el virreinato peruano, y para darle forma a su visión de un justo régimen por venir. El autor representa principalmente las acciones diarias de los conquistadores como emblemas de los vicios, afincándose especialmente en los injustos castigos inflingido a los indios (fig. 4) ${ }^{27}$. Así, en su manuscrito, el autor retoma las referencias visuales europeas para reflejar la situación indígena dentro del régimen colonial.

En general, las ilustraciones de Guamán Poma revelan un profundo conocimiento de los modelos europeos, en particular de la Crónica Mundial de Schedel publicada en Nuremberg en 1493. La mayoría de las imágenes bíblicas y geográficas utilizadas por el cronista andino señalan este referente, pero a diferencia del libro nórdico la crónica peruana carece de una escena completa del Juicio Universal. Esta ausencia puede ser fácilmente justificada ya que dentro del pensamiento andino no existe lugar para un día final. La cosmología andina está compuesta por una serie de mundos o reinos en constante transformación, instaurados luego de cataclismos políticos o naturales. Así, la Coronica i Buen Gobierno constituye en sí mismo un vaticinio o deseo de que se produzca un nuevo pachacuti que traería un régimen de vida mejor, o al menos más justo que aquél impuesto por las autoridades españolas ${ }^{28}$.

Por otro lado, aunque no en una escena unificada, Guamán Poma usa en su libro algunos de los estereotipos visuales del Juicio Universal, pero de una manera más personal. Su representación del Paraíso (fig. 5), por ejemplo, lo presenta como una ciudad amurallada en consonancia con los modelos iconográficos españoles anteriormente estudiados; sin embargo, su ciudad celestial está totalmente vacía. Este detalle se entiende claramente si tomamos en cuenta los comentarios del autor, quien dentro de su mundo contemporáneo no encuentra seres humanos virtuosos capaces de alcanzar tal lugar. En el mismo tono, la «Boca del Infierno» dibujada

\footnotetext{
${ }^{23}$ MacCormack, Sabine. «Pachacuti: Miracles, Punishments, and Last Judgment: Visionary Past and Prophetic Future in Early Colonial Peru». The American Historical Review, vol. 93, octubre 1988, pp. 960-1006

${ }^{24}$ MacCormack, Sabine. Op. cit., pp. 961

${ }^{25} \mathrm{Al}$ contrario de muchos autores que consideran este proceso de transculturación un sincretismo, MacCormack enfatiza que la yuxtaposición de nociones cristianas y andinas generó diversos conflictos y contradicciones, pero nunca cambió las bases cosmológicas andinas. Ver ibid.

${ }^{26}$ Guamán Poma de Ayala, Felipe. Nueva crónica y buen gobierno, Madrid, 1987. Los estudios más completos sobre esta obra los ha realizado Rolena Adorno. Ver Adorno, Rolena. Guaman Poma: writing and resistance in colonial Peru, Austin, 1986; Adorno, Rolena. Cronista y príncipe: la obra de don Felipe Guamán Poma de Ayala, Lima, 1989.

${ }^{27}$ Para el estudio del tema de vicios y virtudes en la obra de Guamán Poma consultar López-Baralt, Mercedes. «La iconografía de vicios y virtudes en el arte de reinar del autor andino: Emblemática política al servicio de una tipología cultural americana», Icono y conquista: Guamán Poma de Ayala, Madrid, 1988, pp. 291-382.

${ }^{28}$ Cfr. López-Baralt, Mercedes. Op. cit., pp. 302.
}

AEA, LXXV, 2002, 299, pp. 293 a 334 

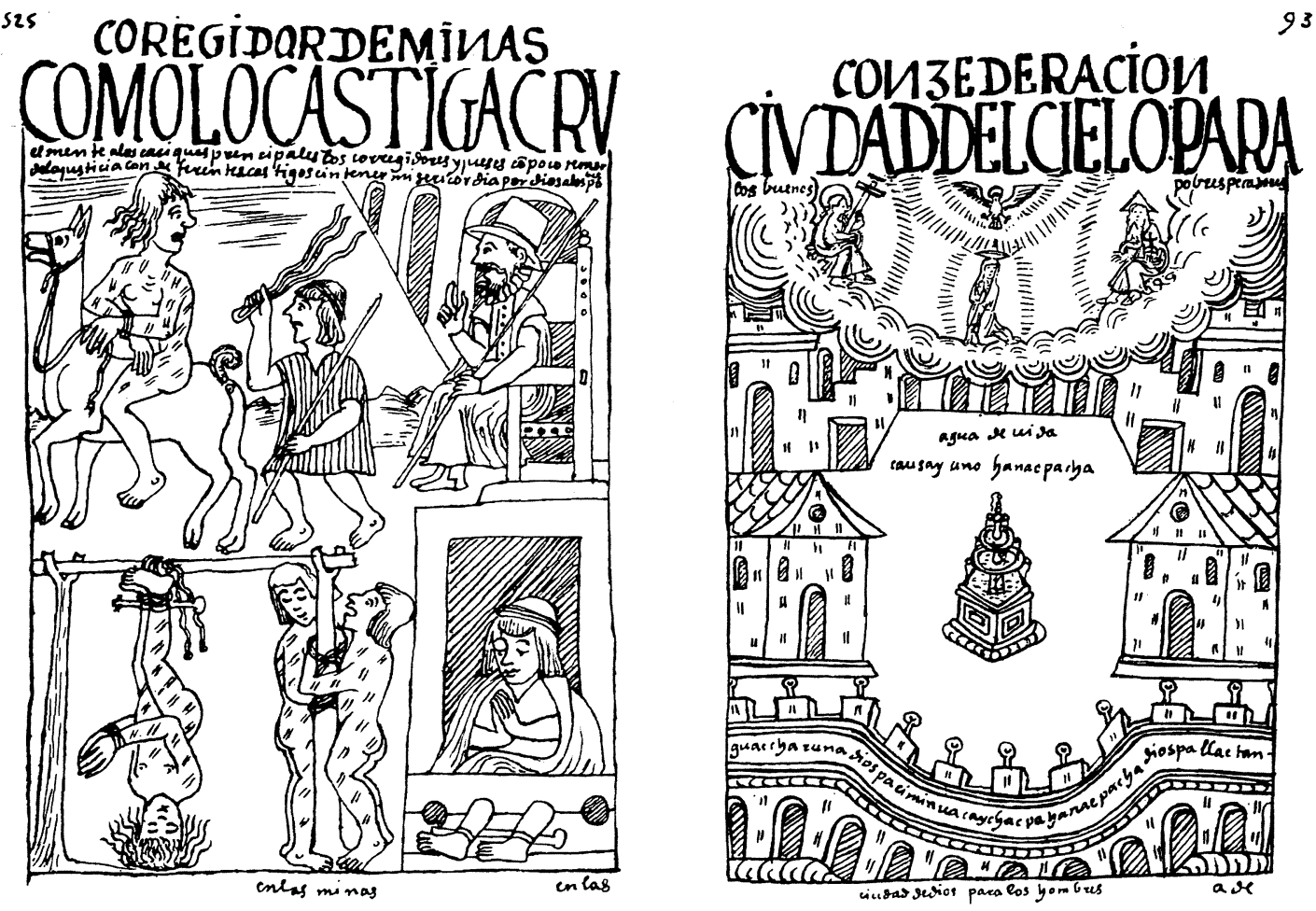

$94^{\mathrm{T}}$

831
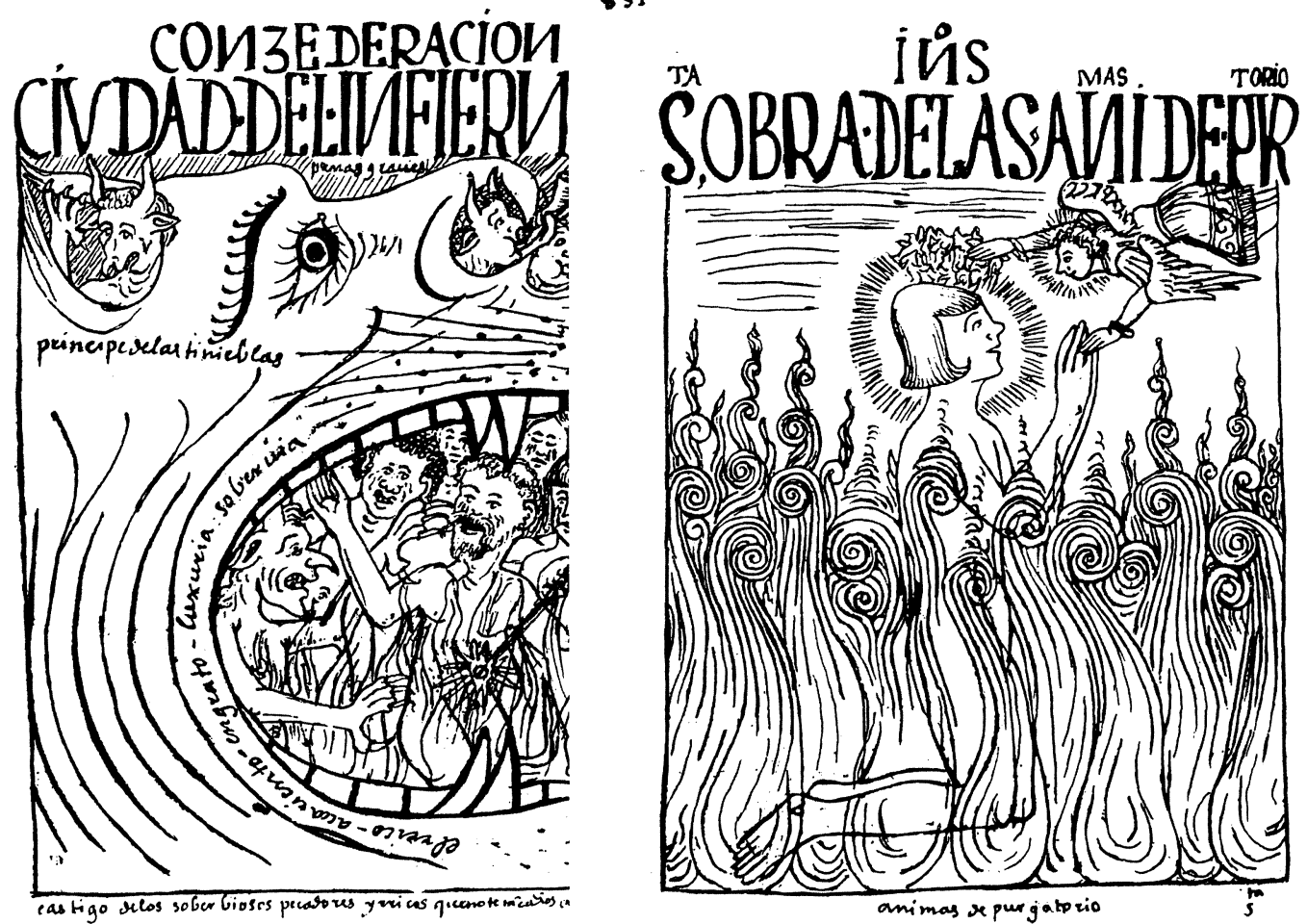

Fig. 4. Guamán Poma de Ayala, Crónica y Buen Gobierno, folio relatando castigos impuestos a los indios, 1585-1635. Real Biblioteca de Copenhague, Dinamarca.

Fig. 5. Guamán Poma de Ayala, Crónica y Buen Gobierno, folio representando el Paraíso.

Fig. 6. Guamán Poma de Ayala, Crónica y Buen Gobierno, folio representado el Infierno.

Fig. 7. Guamán Poma de Ayala, Crónica y Buen Gobierno, folio representando el purgatorio. 
por Guamán Poma (fig. 6), sigue también de cerca los modelos artísticos españoles, presentando esta vez, y en contraposición a la representación celestial, un lugar totalmente abarrotado de representantes de todas las etnias. El reflejo de la visión del autor sobre la realidad circundante resulta aquí evidente.

Por otro lado, el purgatorio de Guamán Poma (fig. 7) es un lugar donde las almas, en vez de ser salvadas, son coronadas. Pareciera que el cronista andino ha reinterpretado este icono europeo bajo la noción nativa de pachacuti, donde castigos, milagros y juicios existen simultáneamente, ocurriendo sin mediación ninguna de la voluntad humana ${ }^{29}$. Así, los tradicionales modelos pictóricos españoles del Juicio Universal fueron traducidos por el cronista andino en escenas de un «mundo al revés» establecido luego del último pachacuti: un purgatorio terrenal instaurado a partir de la Conquista.

En resumen, las representaciones seicentistas del Juicio Universal en los dominios hispánicos entrañaban, entre otras, funciones rituales y admonitorias: ellas reflejaban las ideas contemporáneas de justicia y las consecuencias de su transgresión, exhortando así a sus observadores a llevar una vida virtuosa. Como tales, las imágenes del Juicio Universal pasaron a formar parte del repertorio cultural del pueblo español, como arquetipos visuales de los dos reinos entre los cuales su existencia mortal sólo cobraba sentido: el Reino terreno de la monarquía católica y el Reino futuro del más allá cristiano. Sin embargo, estas escenas no transmitieron las mismas ideas a todos los súbditos de la corona española. Mientras que los Juicios Finales peninsulares exponían conceptos de autoridad bastante homogéneos donde la geografía del más allá sólo fue adaptada a puntuales referencias locales, en los territorios americanos experimentaron transformaciones más radicales. En los Andes, por lo menos, el lineal y antitético concepto católico del fin del mundo fue yuxtapuesto a la cíclica y dual idea del pachacuti nativo, donde castigos, milagros y juicios se mezlcan en eternas series de revoluciones históricas.

Mónica Domínguez Torres

Departamento de Bellas Artes, Universidad de Toronto

${ }^{29}$ Cfr. MacCormack, Sabine. Op. cit., pp. 993.

AEA, LXXV, 2002, 299, pp. 293 a 334 